\title{
ERRATUM
}

\section{Haplotype analysis of the CAG and CCG repeats in 21 Brazilian families with Huntington's disease}

Luciana de A Agostinho, Catielly F Rocha, Enrique Medina-Acosta, Hazel N Barboza, Antônio F Alves da Silva, Simão PF Pereira, Iane dos Santos da Silva, Eduardo R Paradela, André L dos S Figueiredo, Eduardo de M Nogueira, Regina MP Alvarenga, Pedro Hernan Cabello, Suely R dos Santos and Carmen LA Paiva

Journal of Human Genetics (2012) 57, 810; doi:10.1038/jhg.2012.125

Correction to: Journal of Human Genetics (2012) 57, 796-803;

doi:10.1038/jhg.2012.120; published online 11 October 2012

After the publication of this article, an error has been noticed in the Table 1. The error has now been rectified, and the correct Table 1 appears in this issue. The html and online pdf versions have also been rectified. 